\title{
Partial Purification and Some Properties of an Aromatic-amino-acid and an Aspartate Aminotransferase in Brevibacterium linens 47
}

\author{
By CHANG-WON LEE* AND MICHEL J. DESMAZEAUD \\ Laboratoire de Microbiologie Laitière, INRA, Centre de Recherches Zootechniques, \\ 78350 Jouy-en-Josas, France
}

(Received 27 June 1984; revised 6 September 1984)

\begin{abstract}
An L-aromatic-amino-acid aminotransferase (AT-IA) and an L-aspartate aminotransferase (AT-IB) were partially purified from Brevibacterium linens 47 grown on L-phenylalanine as sole nitrogen source and some properties were examined. Both enzymes were active with L-aromatic amino acids and L-aspartate. AT-IA showed 6 to 12 times higher affinity and slightly higher $V_{\max }$ for the aromatic amino acids than for aspartate. AT-IB had higher affinity for tryptophan and tyrosine than for aspartate. However, this enzyme showed 6 to 10 times higher $V_{\max }$ for the latter than for the aromatic amino acid substrates. Both enzymes had similar $\mathrm{pH}(8.5-9.0)$ and temperature $\left(37-40^{\circ} \mathrm{C}\right)$ optima, but they differed in their molecular weights ( 126000 for IA and 81000 for IB) and markedly in their thermostability. At $50^{\circ} \mathrm{C}$, AT-IB was 14 times more rapidly inactivated and its inactivation rate also increased more rapidly (z-value, $7.9^{\circ} \mathrm{C}$ ) as the temperature increased than AT-IA (z-value, $15 \cdot 5^{\circ} \mathrm{C}$ ). The cofactor pyridoxal- $5^{\prime}$-phosphate was tightly bound to both enzymes. Two enzymes co-eluted on DEAE-Trisacryl $\mathbf{M}$ column chromatography at $\mathrm{pH} 7.5$ and could be separated by chromatography on a hydroxyapatite (HA-Ultrogel) column at the same pH. Chromatography on hydroxyapatite of AT-I from cells grown on L-phenylalanine and on ammonium sulphate revealed that AT-IA was present only in phenylalanine grown cells. AT-IB was present in both extracts at similar levels, suggesting that it is constitutive. The inducibility of IA suggested that it has an in vivo catabolic role. AT-IA is probably the key enzyme for the utilization of the aromatic amino acids as sole nitrogen sources in $B$. linens 47.
\end{abstract}

\section{INTRODUCTION}

Aminotransferases in general have broadly overlapping substrate specificities and can catalyse in vitro the reversible transamination reactions, their role in vivo being usually determined by enzyme synthesis regulation (repressibility or inducibility) as in prokaryotic cells and/or by cellular organization, i.e. occurrence mainly in particular organs or organelles, as in higher organisms and eukaryotic micro-organisms (Jensen \& Calhoun, 1981). L-Aromaticamino-acid :2-oxoglutarate aminotransferase (EC 2.6.1.57), also active for L-aspartate, is a ubiquitous enzyme in micro-organisms, and catalyses the last step of phenylalanine and tyrosine biosynthesis or the first step of aromatic amino acid catabolism. L-Aspartate :2-oxoglutarate aminotransferase (EC 2.6.1.1) is also widespread in nature, and in animal and plant cells occurs both as mitochondrial and cytosolic isoenzymes. In micro-organisms, both enzymes have been extensively studied in Escherichia coli (Mavrides \& Orr, 1975; Gelfand \& Steinberg, 1977; Powell \& Morrison, 1978) and to a lesser extent in Klebsiella aerogenes (Paris \& Magasanik, $1981 a, b$ ), Pseudomonas aeruginosa (Whitaker et al., 1982), Flavobacterium spp. (Beschle et al., 1982) and Saccharomyces cerevisiae (Kradolfer et al., 1982; Yagi et al., 1982). With the E. coli

Abbreviations: MVL medium, mineral salts/vitamins/lactate medium; PLP, pyridoxal-5'-phosphate. 
enzymes, considerable overlap of substrate specificity has been observed and they also share some similarities in their physical properties such as molecular weights and isoelectric points (Mavrides \& Orr, 1975; Powell \& Morrison, 1978). Thus in E. coli, there has been considerable confusion on the identity and non-identity of these two enzymes (Collier \& Kohlhaw, 1972; Mavrides \& Orr, 1975), and it is only recently that their non-identity has been unequivocally established by the sequential mutagenesis approach (Gelfand \& Steinberg, 1977) and subsequent enzymological studies (Powell \& Morrison, 1978). Moreover, in spite of their probable importance in the organic nitrogen metabolism of bacteria there has been relatively little investigation of these enzymes other than in $E$. coli.

In Brevibacterium linens 47 we have separated two activities of aromatic-amino-acid aminotransferase (AT-I and AT-II) on DEAE-Trisacryl M column chromatography and on polyacrylamide gel electrophoresis (C.-W. Lee \& M. J. Desmazeaud, unpublished results). During the purification of AT-I for further characterization, it was further resolved into two activities. We describe here the partial purification and characterization of these two activities.

\section{METHODS}

Organism and culture conditions. Brevibacterium linens 47 was used throughout this investigation and is described elsewhere (Boyaval et al., 1984). Mineral salts/vitamins/lactate (MVL) medium contained per litre: $\mathrm{KH}_{2} \mathrm{PO}_{4}$, $0.24 \mathrm{~g} ; \mathrm{K}_{2} \mathrm{HPO}_{4}, 1.7 \mathrm{~g} ; \mathrm{CaCl}_{2}, 25 \mathrm{mg} ; \mathrm{MgSO}_{4} .7 \mathrm{H}_{2} \mathrm{O}, 0.2 \mathrm{~g} ; \mathrm{FeSO}_{4} . \mathrm{H}_{2} \mathrm{O}, 5 \mathrm{mg} ; \mathrm{NaCl}, 10 \mathrm{~g}$; sodium DL-lactate $(60 \%, w / v$ syrup; Sigma), $16 \cdot 6 \mathrm{~g}$; and $5 \mathrm{ml}$ of the vitamin solution of Bousfield (1972). The nitrogen source was either L-phenylalanine (12 mM) for 'induced' cells or ammonium sulphate (12 mM) for 'non-induced' cells. The medium was adjusted to $\mathrm{pH} 7 \cdot 3$ with $0 \cdot 1 \mathrm{M}-\mathrm{NaOH}$ and autoclaved at $121^{\circ} \mathrm{C}$ for $20 \mathrm{~min}$, except for the vitamin solution which was added aseptically after sterilization by filtration (pore size $0 \cdot 2 \mu \mathrm{m}$; Schleicher \& Schüll, Dassel, FRG) to the sterile medium. The organism was grown in $200 \mathrm{ml}$ batches of medium in one litre conical flasks inoculated with $1 \%(\mathrm{v} / \mathrm{v})$ of a $24 \mathrm{~h}$ grown culture in the same medium. Cultures were incubated at $26^{\circ} \mathrm{C}$ on a reciprocal shaker (100 r.p.m.) to late exponential phase (48 to $72 \mathrm{~h}$ ). Stock cultures were maintained on brain heart infusion agar (Difco) slants and plates. Cell growth was followed by the optical density at $650 \mathrm{~nm}$.

Preparation of crude extracts. Cells were harvested by centrifugation at $10000 \mathrm{~g}$ for $10 \mathrm{~min}$ at $4{ }^{\circ} \mathrm{C}$ and washed twice in $50 \mathrm{~mm}$-potassium phosphate buffer, $\mathrm{pH} 7.5$ at $4{ }^{\circ} \mathrm{C}$. Then $1 \mathrm{~g}$ (wet wt) of cell paste was resuspended in $5 \mathrm{ml}$ $50 \mathrm{~mm}$-potassium phosphate buffer, $\mathrm{pH} \mathrm{7.5}$, containing $2 \mathrm{mM}-2$-mercaptoethanol, $1 \mathrm{~mm}-\mathrm{EDTA}$ and $0.1 \mathrm{mM}-$ pyridoxal-5'-phosphate (PLP) ('supplemented' buffer), and cells were disrupted by ultrasonic treatment of five periods of $60 \mathrm{~s}$ at $0.7 \mathrm{~A}$ (Ultrasonic, Meaux, France) at $0{ }^{\circ} \mathrm{C}$. Cell debris and unbroken cells were removed by centrifugation at $4^{\circ} \mathrm{C}$ for $20 \mathrm{~min}$ at $33000 \mathrm{~g}$. The supernatant contained 1.5 to $2.0 \mathrm{mg}$ proteins ml-1 and was termed the crude extract.

Enzyme assays. Both AT-IA and AT-IB were active for the substrate pair L-phenylalanine : 2 -oxoglutarate, and their activities in column eluates were conveniently assayed as L-phenylalanine :2-oxoglutarate aminotransferase.

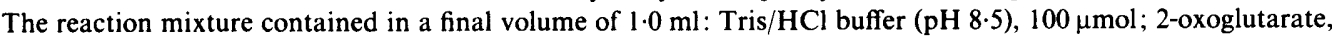
$10 \mu \mathrm{mol}$; PLP, $0.05 \mu \mathrm{mol}$; and enzyme, 0.3 to 5 milliunits $(\mathrm{mU})$. After preincubation for $5 \mathrm{~min}$ at $37^{\circ} \mathrm{C}$, the reaction was started by the addition of $10 \mu \mathrm{mol} \mathrm{L}$-phenylalanine and stopped after $10 \mathrm{~min}$ with $0.5 \mathrm{ml} 2 \mathrm{M}-\mathrm{NaOH}$. $A_{320}$ was measured against a blank in which enzyme was omitted. To calculate the enzyme activity, a molar absorption coefficient $\left(\varepsilon_{M}\right)$ of $17500 \mathrm{M}^{-1} \mathrm{~cm}^{-1}$ for phenylpyruvate was used (Dawson et al., 1969). For the enzyme assay with alternative aromatic amino acids as amino group donors, the amino group donor and acceptor were added at similar concentrations. The activities of tyrosine aminotransferase and tryptophan aminotransferase were measured at $330 \mathrm{~nm}$, and the following values of $\varepsilon_{M}$ were respectively applied for the conversion of $A_{330}$ into enzyme activities: $19500 \mathrm{M}^{-1} \mathrm{~cm}^{-1}$ for 4-hydroxybenzaldehyde formed from 4-hydroxyphenylpyruvate in alkali (Diamondstone, 1966), and $15000 \mathrm{~m}^{-1} \mathrm{~cm}^{-1}$ for indolpyruvate (Collier \& Kohlhaw, 1972). Aspartate aminotransferase activity was assayed by a modification of the method of Sizer \& Jenkins (1962). The reaction

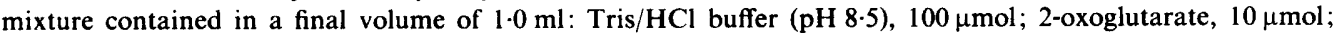
$\mathrm{NADH}, 100 \mu \mathrm{g}$; malate dehydrogenase (EC 1.1.1.37), $2 \mathrm{U}$; and enzyme. The reaction was started by the addition of $10 \mu \mathrm{mol} \mathrm{L}$-aspartate, and carried out at $37^{\circ} \mathrm{C}$. The decrease in $A_{340}$ was followed with a Cary 219 recording spectrophotometer (Varian Associates Inc., Palo Alto, Calif., USA). The $\varepsilon_{M}$ value of $6200 \mathrm{~m}^{-1} \mathrm{~cm}^{-1}$ was assumed for NADH in calculating the enzyme activity.

Definition of enzyme unit and specific activity. One unit of aminotransferase is defined as that amount which produces $1 \mu \mathrm{mol}$ of corresponding 2-oxo acid $\mathrm{min}^{-1}$ under the conditions described. Specific activity is expressed as milliunits ( $\mathrm{mU} ; \mathrm{nmol} \mathrm{min}^{-1}$ ) $\mathrm{mg}_{\text {protein }}{ }^{-1}$.

Protein assay. Protein concentrations after each purification step were determined by the 'standard' method of Bradford (1976), using crystalline bovine serum albumin (Serva Feinbiochemica, Heidelberg, FRG) as a standard, while those in column effluents were monitored by $A_{280}$. 
Enzyme purification. All steps were carried out at 2 to $4{ }^{\circ} \mathrm{C}$ unless indicated otherwise. Freshly prepared $20 \%$ $(\mathrm{w} / \mathrm{v})$ streptomycin sulphate solution, which had been adjusted to $\mathrm{pH} 7.0$ with $1 \mathrm{M}-\mathrm{NaOH}$, was added to crude extracts with constant stirring to a final concentration of $0.5 \%(\mathrm{w} / \mathrm{v})$. After standing for $15 \mathrm{~min}$, insoluble material was removed by centrifugation. Ammonium sulphate fractionation of the supernatant was carried out by adding solid ammonium sulphate, and protein precipitated between 50 and $75 \%$ saturation was collected by centrifugation. The precipitate was dissolved in a minimum volume of 'supplemented' $0.05 \mathrm{M}$-buffer and passed through a Sephadex G-25 column (bed volume, $90 \mathrm{ml}$; diameter, $2.4 \mathrm{~cm}$ ), equilibrated previously with the same buffer. Eluates were applied to a column (bed volume, $70 \mathrm{ml}$; diameter, $2.5 \mathrm{~cm}$ ) of DEAE-Trisacryl M (Industrie Biologique Française, Clichy, France), pre-equilibrated with the 'supplemented' 0.05 M-buffer. Proteins were eluted with a linear gradient of $\mathrm{NaCl}(0$ to $0.4 \mathrm{M}$ in a total volume of $400 \mathrm{ml}$ of the starting buffer). Fractions of $3.4 \mathrm{ml}$ were collected and those contained in the major peak (AT-I) of the activity were pooled and concentrated by addition of solid ammonium sulphate $\left(0.56 \mathrm{~g} \mathrm{ml}^{-1}\right)$. The precipitate collected by centrifugation was dissolved in a minimal volume of 5 mm-potassium phosphate buffer, $\mathrm{pH} 7.5$ and desalted through a Sephadex G- 25 column. Active fractions were applied to an hydroxyapatite (HA-Ultrogel; IBF) column (bed volume, $26 \mathrm{ml}$; diameter, $1.6 \mathrm{~cm}$ ) previously equilibrated with $5 \mathrm{~mm}$-potassium phosphate buffer, $\mathrm{pH} 7.5$. After washing with $83 \mathrm{ml}$ of the starting buffer, a linear gradient was applied from 5 to $200 \mathrm{~mm}$-potassium phosphate buffer, $\mathrm{pH} 7.5$ in a total volume of $140 \mathrm{ml}$. Active fractions were pooled and concentrated by ammonium sulphate precipitation as described above. Protein precipitate was redissolved in $1.0 \mathrm{ml}$ of 'supplemented' $0.1 \mathrm{M}$-buffer and applied to a Sephacryl S-200 superfine (Pharmacia) gel filtration column (bed volume, $96.2 \mathrm{ml}$; diameter, $1.4 \mathrm{~cm}$; void volume, $54.5 \mathrm{ml}$ ). Fractions of $0.68 \mathrm{ml}$ were collected at $15.7 \mathrm{ml} \mathrm{h}^{-1}$ and portions analysed for enzyme activity. Active fractions were pooled and concentrated by Immersible CX-10 (molecular weight cut, $10^{4}$ daltons; Millipore) Portions $(2.5 \mathrm{ml})$ of concentrated preparation were passed through a small Sephadex G-25 column (PD-10; Pharmacia) pre-equilibrated with $50 \mathrm{~mm}$-potassium phosphate buffer, $\mathrm{pH} 7.5$, and used for further characterization.

Polyacrylamide slab gel electrophoresis. The procedure of Davis (1964) was followed except that the concentration of the running gel buffer was $0.375 \mathrm{M}$. Electrophoresis was for $4 \mathrm{~h}$ at $150 \mathrm{~V}$ at $4{ }^{\circ} \mathrm{C}$. The gel was stained for protein with Coomassie brilliant blue R-250 (Serva) or for the phenylalanine aminotransferase activity by the procedure of Ryan et al. (1972). The activity staining mixture contained per $\mathrm{ml}$ : L-phenylalanine, $2 \mathrm{mg} ; 2$ oxoglutarate, $1 \mathrm{mg}$; NAD, $2 \mathrm{mg}$; phenazine methosulphate, $50 \mu \mathrm{g}$; nitroblue tetrazolium, $0.5 \mathrm{mg}$; glutamate dehydrogenase, $0.1 \mathrm{U}$; PLP, $0.1 \mathrm{mg}$; and $0.1 \mathrm{M}$-Tris/HCl buffer, pH 8.5. In blanks, 2-oxoglutarate or the amino acid was omitted.

Estimation of molecular weights. The same column of Sephacryl S-200 used for the last step of purification, was equilibrated with 'supplemented' $0 \cdot 1 \mathrm{M}$-buffer and calibrated with the following molecular weight markers: cytochrome $c, 12500$; chymotrypsinogen A, 25000; hen egg albumin, 45000; bovine serum albumin, 68000; lactate dehydrogenase, 140000 ; and catalase, 240000.

Thermal inactivation kinetics. Concentrated enzyme preparation after step 5 (Table 1) was used, after passing through a Sephadex G-25 column which was pre-equilibrated with $0 \cdot 1 \mathrm{M}$-potassium phosphate buffer, pH 7.5. Portions of $1.0 \mathrm{ml}$ of diluted enzyme solution in glass test tubes $(6 \times 50 \mathrm{~mm})$ were pre-incubated in a water bath at the desired temperature $\left( \pm 0 \cdot 2^{\circ} \mathrm{C}\right)$. The increase in temperature of the stirred enzyme solution was monitored and the sampling $(50 \mu \mathrm{l})$ at zero heating time was done when it attained the desired temperature. Thereafter, $50 \mu \mathrm{l}$ samples were removed and immediately transferred into test tubes containing $950 \mu \mathrm{l}$ cold $50 \mathrm{~mm}$-potassium phosphate buffer, pH 7.5, which were kept in an ice bath until all samples were taken. Residual activity was assayed as phenylalanine aminotransferase, and expressed as percentage of the activity at zero heating time.

Thermodynamic parameters of thermal inactivation were obtained graphically by plotting $\log \left(k^{\prime} / T\right)$ versus $1 / T$ according to Eyring's absolute reaction rate equation (Aylward \& Haisman, 1969):

$$
k^{\prime}=K \frac{k T}{h} e^{\left(-\Delta H^{*} / R T\right)} \mathrm{e}^{\left(\Delta S^{*} / R\right)}
$$

where $k^{\prime}$ is the specific rate constant; $K$, transmission coefficient; $k$, Boltzman's constant; $h$, Planck's constant; $T$, absolute temperature; $R$, gas constant; $\Delta H^{*}$, change in enthalpy for the activation process of thermal inactivation of the enzyme; $\Delta S^{*}$, change in entropy for the same process. In practice, $k^{\prime}$ was obtained by $2 \cdot 303 / D(D$, decimal reduction time), $\Delta H^{*}$ by $-2 \cdot 303 R \times$ slope, and $\Delta S^{*}$ from $2 \cdot 303 R$ [intercept $+\log (K k / h)$ ], $K$ being taken as unity (Aylward \& Haisman, 1969). The free energy of activation for the thermal inactivation of the enzyme was calculated from the equation: $\Delta F^{*}=\Delta H^{*}-T \Delta S^{*}$.

\section{RESULTS}

\section{Comparison of chromatographic profiles of phenylalanine aminotransferase activity in crude} extracts

When crude extracts of 'induced' and 'non-induced' cells were chromatographed on a DEAETrisacryl M column, two activity peaks (AT-I and AT-II) were obtained (Fig. 1). The level of 


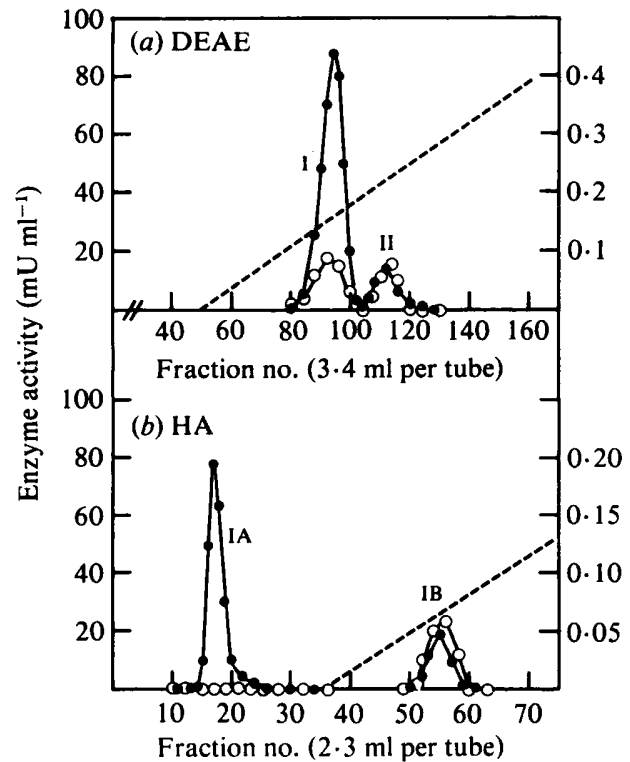

Fig. 1

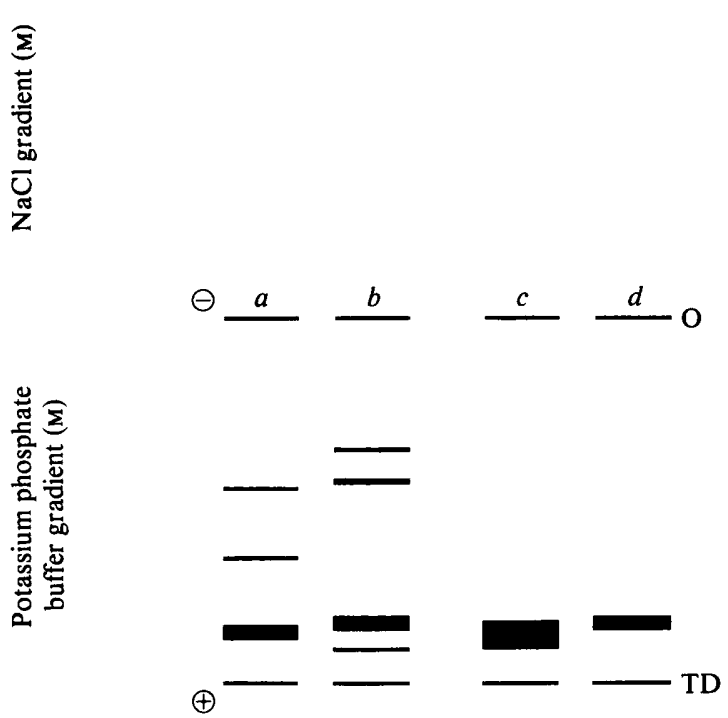

Fig. 2

Fig. 1. Aminotransferase activity profiles of crude extracts of $B$. linens 47 . Enzyme activity was assayed as L-phenylalanine : 2 -oxoglutarate aminotransferase. Extracts were prepared from cells grown on MVL medium containing L-phenylalanine $(O)$ or ammonium sulphate $(O)$ as sole nitrogen sources, and $40 \mathrm{mg}$ proteins of each extract were chromatographed on DEAE-Trisacryl M (a). The activity of AT-I from each extract was collected and re-chromatographed on HA-Ultrogel (b). Linear gradients (---) of $\mathrm{NaCl}$ or potassium phosphate buffer, $\mathrm{pH} 7.5$ were as indicated.

Fig. 2. Polyacrylamide slab gel electrophoresis of AT-IA $(a, c)$ and AT-IB $(b, d)$. Enzyme preparations obtained after step 5 (Table 1) were used: $(a, b)$ protein staining; $(c, d)$ activity staining for the Lphenylalanine : 2-oxoglutarate aminotransferase as described in Methods; $\mathrm{O}$, origin; $\mathrm{TD}$, tracking dye front (bromophenol blue).

AT-I of 'induced' cells was 5 to 10 times higher than that of 'non-induced' cells, while the activity of AT-II was similar in both extracts. AT-I of 'induced' cells was separated into two activities (AT-IA and AT-IB) by chromatography on an HA-Ultrogel column (see below). To determine whether the higher level of enzyme activity of 'induced' cells was due to the increase of the level of AT-IA or AT-IB alone or both, AT-I from 'induced' and 'non-induced' cells were chromatographed on HA-Ultrogel and activity profiles were compared. When AT-I, collected from DEAE-Trisacryl $M$ column chromatography of the cell extract of 'induced' cells, was rechromatographed on HA-Ultrogel, two activity peaks were eluted (AT-IA and AT-IB in eluting order). By contrast, AT-I from 'non-induced' cells gave only one activity peak comparable to AT-IB of 'induced' cells, which suggested that the activity AT-IB was present in both extracts. No significant difference was observed in the activity level of AT-IB in both extracts. The results showed that AT-IA was an inducible enzyme whilst AT-IB appears to be a constitutive enzyme.

Separation and partial purification of the aromatic-amino-acid aminotransferase $(A T-I A)$ and the aspartate aminotransferase $(A T-I B)$ in B. linens 47

AT-IA and AT-IB, which could be classified respectively as an aromatic-amino-acid aminotransferase and an aspartate aminotransferase for the reasons given below, were enriched respectively about 80 - and 54 -fold for their primary activities by the purification steps shown in Table 1. 
Table 1. Summary of partial purification of an aromatic-amino-acid aminotransferase $(A T-I A)$ and an aspartate aminotransferase $(A T-I B)$ from $B$. linens 47

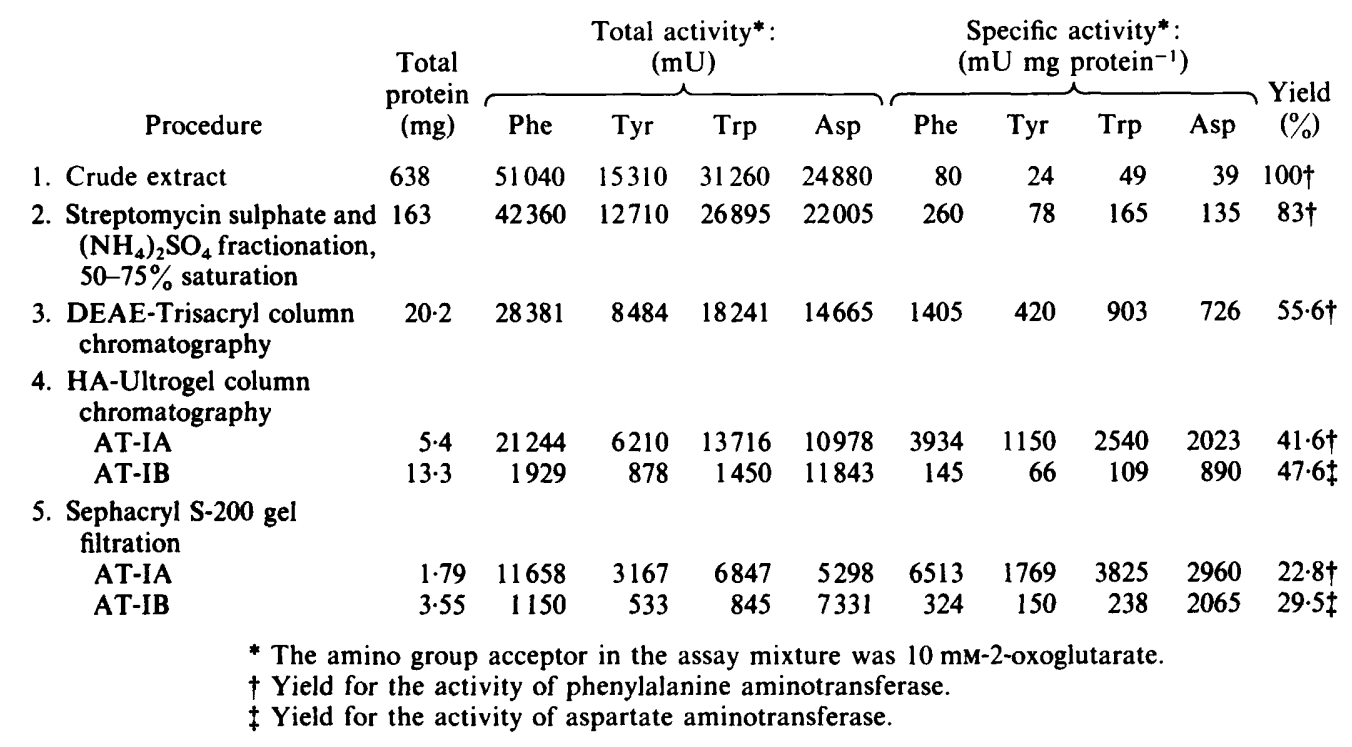

Table 2. Kinetic parameters of partially purified aminotransferases $A T-I A$ and $A T-I B$ from B. linens 47

The buffer used was $0.1 \mathrm{M}$-Tris/ $\mathrm{HCl}, \mathrm{pH} \mathrm{8.5.} \mathrm{Assay} \mathrm{conditions} \mathrm{are} \mathrm{given} \mathrm{in} \mathrm{the} \mathrm{text.} \mathrm{The} \mathrm{constants} \mathrm{were}$ determined from Lineweaver-Burk plots of the activities at various substrate concentrations, except for the $V_{\max }$ values marked by $\dagger$, which are the activities at the indicated substrate concentrations.

\begin{tabular}{|c|c|c|c|c|c|}
\hline \multirow{2}{*}{$\begin{array}{l}\text { Amino group } \\
\text { donor (mM) }\end{array}$} & \multirow{2}{*}{$\begin{array}{c}\text { Amino group } \\
\text { acceptor* }\end{array}$} & \multicolumn{2}{|c|}{ Apparent $K_{\mathrm{m}}(\mathrm{mM})$} & \multicolumn{2}{|c|}{$V_{\max }\left(\mathrm{mU} \mathrm{mg}\right.$ protein $\left.{ }^{-1}\right)$} \\
\hline & & IA & $\overrightarrow{\text { IB }}$ & IA & IB \\
\hline L-Phenylalanine & 2-Oxoglutarate & $1 \cdot 3$ & $6 \cdot 2$ & 6714 & 485 \\
\hline L-Phenylalanine (10) & Pyruvate & ND & ND & $728+$ & $31+$ \\
\hline DL-Phenylalanine (10) & 2-Oxoglutarate & ND & ND & $5393 \dagger$ & $272+$ \\
\hline L-Tyrosine & 2-Oxoglutarate & 1.4 & 1.6 & 4040 & 343 \\
\hline L-Tyrosine (1) & Pyruvate & ND & ND & $308+$ & $23+$ \\
\hline DL-Tyrosine $(0.5)$ & 2-Oxoglutarate & ND & ND & $423 \dagger$ & $38 \dagger$ \\
\hline L-Tryptophan & 2-Oxoglutarate & 0.7 & 0.6 & 4780 & 273 \\
\hline L-Tryptophan (10) & Pyruvate & ND & ND & $600 \dagger$ & $37 \dagger$ \\
\hline DL-Tryptophan (10) & 2-Oxoglutarate & ND & ND & $2625+$ & $165 t$ \\
\hline L-Aspartate & 2-Oxoglutarate & $8 \cdot 4$ & 3.8 & 3356 & 2785 \\
\hline
\end{tabular}

ND, Not determined.

* Amino group acceptors were added at $20 \mathrm{~mm}$ in assay mixtures.

Electrophoretic studies. When $20 \mu \mathrm{g}$ of the enzyme proteins of AT-IA and AT-IB (after step 5) were electrophoresed on a polyacrylamide slab gel at $\mathrm{pH} 8.9$, protein staining showed one major band $\left(R_{F}=0.87\right)$ and two minor bands for AT-IA, and one major band $\left(R_{F}=0.84\right)$ and three minor ones for AT-IB. Activity staining of duplicate gel showed one activity band for each enzyme preparation, which corresponded to the major protein bands (Fig. 2). These activity bands were absent in blanks in which either 2-oxoglutarate or the amino acid substrate was omitted from the complete staining mixture.

Substrate specificity and kinetic parameters. Both AT-IA and AT-IB were active for Lphenylalanine, L-tyrosine, L-tryptophan and L-aspartate (Table 2) and were completely inactive 


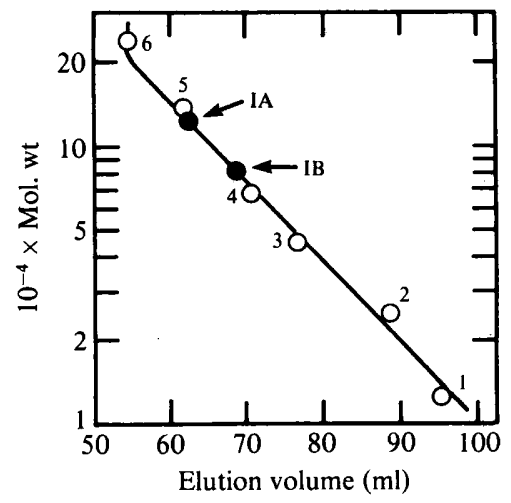

Fig. 3

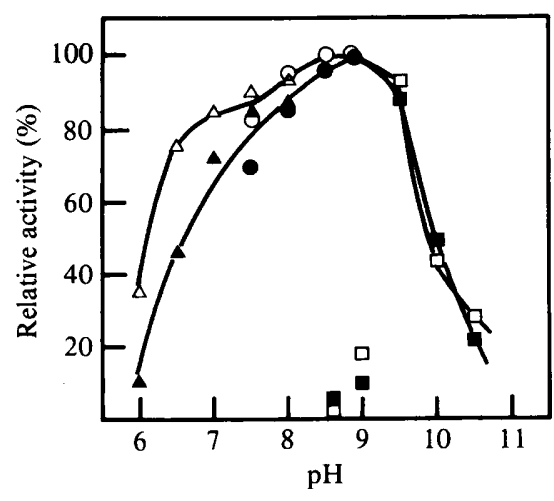

Fig. 4

Fig. 3. Estimation of the molecular weights of AT-IA and AT-IB by gel filtration on Sephacryl S-200. The standard proteins $(O)$ used were: 1 , cytochrome $c ; 2$, chymotrypsinogen $A ; 3$, hen egg albumin; 4 , bovine serum albumin; 5 , lactate dehydrogenase; 6 , catalase.

Fig. 4. Dependence on $\mathrm{pH}$ of activity of $B$. linens 47 aminotransferases AT-IA (filled symbols) and ATIB (open symbols). Enzyme activity was assayed as L-phenylalanine : 2 -oxoglutarate aminotransferase.

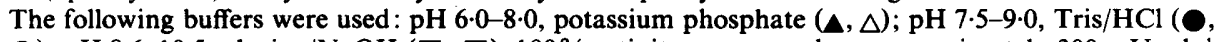
); $\mathrm{pH} 8 \cdot 6-10 \cdot 5$, glycine/ $\mathrm{NaOH}(\mathrm{G}, \square) .100 \%$ activity corresponds to approximately $300 \mathrm{mU} \mathrm{ml}^{-1}$ and $200 \mathrm{mU} \mathrm{ml}^{-1}$ for AT-IA and AT-IB, respectively.

for D-isomers. For all aromatic amino acids, no inhibition of activity for L-amino acid was observed by the $\mathrm{D}$-isomer, when the latter was present at the same concentration as that of Lisomer. AT-IA showed a higher apparent $K_{\mathrm{m}}$ value for aspartate than for the aromatic amino acids, and the lowest $V_{\max }$ for aspartate. Therefore, this enzyme can justly be classified as an Laromatic-amino-acid aminotransferase (EC 2.6.1.57). Though AT-IB showed higher affinity for tryptophan and tyrosine than for aspartate, its 6- to 10-fold higher $V_{\max }$ for aspartate compared to the aromatic amino acids suggested its classification as an aspartate aminotransferase (EC 2.6.1.1). For both enzymes oxalacetate was a good amino group acceptor for the aromatic amino acids (data not shown), but pyruvate acted at a much lower rate (Table 2).

Molecular weight estimation of the enzymes. The apparent molecular weights of the partially purified aminotransferases (after step 5) were estimated by gel filtration on a Sephacryl S-200 column to be 126000 and 81000 for AT-IA and AT-IB, respectively (SD 4000, two runs; Fig. 3). For linear correlation between $\log (\mathrm{mol}$. wt) and elution volumes with Sephacryl S-200, it was important that the molarity of the elution buffer was greater than $0.05 \mathrm{M}$.

pH and temperature optima. Both enzymes had a pH optimum of 8.5 to 9.0 (Fig. 4) for the Lphenylalanine : 2-oxoglutarate aminotransferase activity. AT-IB showed a less symmetrical pH profile than AT-IA, and retained higher relative activity at lower $\mathrm{pH}$ values. With glycine/ $\mathrm{NaOH}$ buffers at $\mathrm{pH} 8 \cdot 5$ and $9 \cdot 0$, the activity was nearly completely inhibited for both enzymes. The reason is not yet clear. Both enzymes also showed similar temperature dependence of the activity and had an optimum at 37 to $40^{\circ} \mathrm{C}$ at $\mathrm{pH} 8.5$. Plotting the logarithm of the activities between 0 to $30^{\circ} \mathrm{C}$ against the reciprocal of the absolute temperature gave straight lines, from which the activation energy was calculated to be $47.7 \mathrm{~kJ} \mathrm{~mol}^{-1}$ and $52.5 \mathrm{~kJ} \mathrm{~mol}^{-1}$ for AT-IA and AT-IB, respectively (Fig. 5).

Stability and thermal inactivation. Both partially purified enzymes could be stored at $4{ }^{\circ} \mathrm{C}$ in 'supplemented' $0.1 \mathrm{M}$-potassium phosphate buffer, $\mathrm{pH} 7.5$, containing $0.02 \%$ sodium azide for at least six months without noticeable loss of activity. Thermal inactivation experiments at several temperatures $\left(37\right.$ to $\left.55^{\circ} \mathrm{C}\right)$ were carried out with the enzyme preparations obtained after step 5 . AT-IA showed biphasic inactivation kinetics, while AT-IB showed monophasic kinetic curves (Fig. 6). The $z$-values, defined as the increase in temperature necessary to produce a 10 -fold 


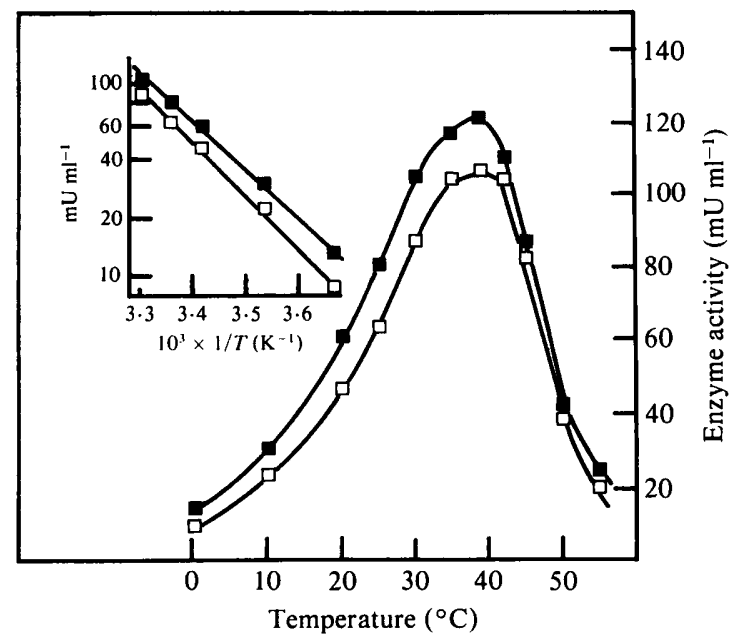

Fig. 5. Dependence on temperature of activity of $B$. linens 47 aminotransferases AT-IA $(\square)$ and AT-IB ( $\square$ ). Activity was assayed as L-phenylalanine : 2 -oxoglutarate aminotransferase. Arrhenius plots of the results in the range $0-30{ }^{\circ} \mathrm{C}$ are given in the inset.

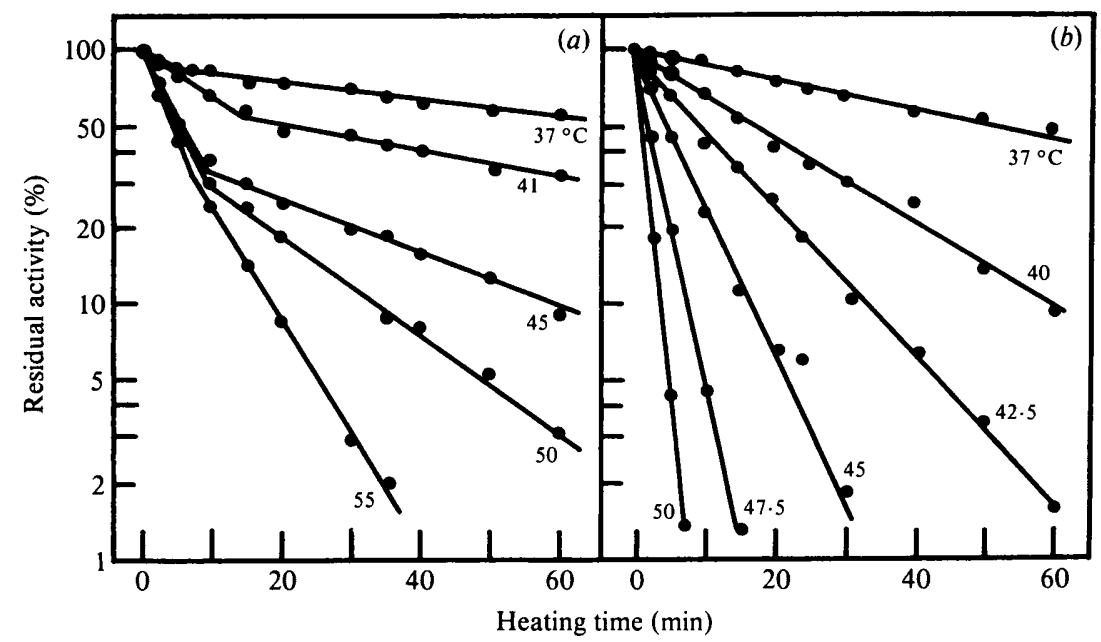

Fig. 6. Thermal inactivation curves of AT-IA $(a)$ and AT-IB $(b)$. Enzymes were in $0 \cdot 1 \mathrm{M}$-potassium phosphate buffer, $\mathrm{pH} 7.5$ and the activity was assayed as L-phenylalanine : 2 -oxoglutarate aminotransferase. Protein concentrations in the enzyme solutions were $40 \mu \mathrm{g} \mathrm{ml}^{-1}$ and $80 \mu \mathrm{g} \mathrm{ml}^{-1}$ for IA and IB, respectively. $100 \%$ residual activity corresponds to $260 \mathrm{mU} \mathrm{ml}^{-1}$ and $25 \mathrm{mU} \mathrm{ml}^{-1}$ for IA and IB, respectively. Experimental details are described in Methods.

Table 3. Thermodynamic constants of the thermal inactivation of aminotransferases AT-IA and $A T-I B$ from $B$. linens 47

The data are given for $50{ }^{\circ} \mathrm{C}$.

$10^{4} \times$

Inactivation

Enzyme

AT-IA

AT-IB rate $\left(\mathrm{s}^{-1}\right)$

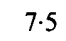

$106 \cdot 6$
$\Delta F^{*}$

(kJ $\mathrm{mol}^{-1}$ )

\section{$98 \cdot 40$}

$91 \cdot 70$
$\Delta H^{*}$

(kJ mol-1) $\left(\mathrm{J} \mathrm{mol}^{-1} \mathrm{~K}^{-1}\right)$

$$
\begin{aligned}
& 120 \cdot 30 \\
& 238 \cdot 90
\end{aligned}
$$

68 
increase in the rate of inactivation $\left(k^{\prime}\right)$, were calculated in the temperature range examined to be $15.5^{\circ} \mathrm{C}$ and $7.9^{\circ} \mathrm{C}$ for AT-IA and AT-IB, respectively. This reflects a considerable difference between the two enzymes. Thermodynamic constants for the activation process of the thermal inactivation of the two enzymes were obtained by plotting the results of Fig. 6 according to Eyring's absolute reaction rate equation (see Methods), and data obtained at $50{ }^{\circ} \mathrm{C}$ are shown in Table 3. In spite of the similar values of the activation energy $\left(\Delta F^{*}\right)$ of thermal inactivation obtained for the two enzymes, the inactivation rate of AT-IB was 14 times higher than that of AT-IA.

Effect of pyridoxal-5'-phosphate. The activities of the final enzyme preparations AT-IA and AT-IB were diminished by only $13 \%$ and $24 \%$, respectively, in the absence of PLP. When the enzymes were dialysed against 1000 vols $50 \mathrm{~mm}$-potassium phosphate buffer, $\mathrm{pH} 7 \cdot 5$, at $4{ }^{\circ} \mathrm{C}$ for $16 \mathrm{~h}$, AT-IA and AT-IB lost, respectively, only $55 \%$ and $67 \%$ of the initial activities. Thus, the cofactor appeared to be tightly bound to the proteins. More than $90 \%$ of the initial activities were restored by the addition of $0.05 \mathrm{~mm}$-PLP to the dialysed enzyme solutions.

\section{DISCUSSION}

In earlier work with Brevibacterium linens 47, two activities (AT-I and AT-II) of aromaticamino-acid aminotransferase were separated on DEAE-Trisacryl M column chromatography of cell extracts (C.-W. Lee \& M. J. Desmazeaud, unpublished results). From the comparison of cell extracts of 'induced' and 'non-induced' cells by the same chromatography, we concluded that AT-I was an inducible enzyme having a minimum level (Fig. 1) which was also observed in cell extracts of 'non-induced' cells. In the present study, it was shown that AT-I was composed of an inducible component and a constitutive one (respectively IA and IB). Because no activity of IA was observed in extracts of 'non-induced' cells on HA-Ultrogel chromatography, it is now clear that the minimum level of AT-I on DEAE-Trisacryl column chromatography was in fact the level of the constitutive enzyme IB which co-eluted with IA from the DEAE-Trisacryl column. Thus we have shown that extracts of $B$. linens 47 contain three distinct aromatic-amino-acid aminotransferases. Two enzymes, AT-IA and AT-IB, were partially purified and some properties were examined. Based on the kinetic parameters, AT-IA was classified as an Laromatic-amino-acid aminotransferase (EC 2.6.1.57) and AT-IB as an L-aspartate aminotransferase (EC 2.6.1.1). The enzymes were most readily distinguished by their heat stability: inactivation rates at $50^{\circ} \mathrm{C}$ were $7.5 \times 10^{-4} \mathrm{~s}^{-1}$ versus $106.6 \times 10^{-4} \mathrm{~s}^{-1}$, respectively, for IA and IB. The entropy changes $\left(\Delta S^{*}\right.$, Table 3$)$ involved in the inactivation process suggested that the thermolability of AT-IB was due more probably to the fragility of second and higher structures as a whole of the enzyme rather than to a simple detachment of the cofactor or minor changes in configuration limited to the active site. In fact, the results of the dialysis of the enzymes showed that the cofactor PLP was tightly bound for both enzymes. AT-IA was 5- to 10-fold induced by the growth of cells on L-phenylalanine as sole nitrogen source. This strongly suggests a catabolic role of the enzyme in vivo. Similarly, an inducible aromatic aminotransferase (AT-3) has been identified in extracts of Pseudomonas aeruginosa (Whitaker et al., 1982). In Escherichia coli and Klebsiella aerogenes, no inducible aromatic-amino-acid aminotransferase has been identified. In $E$. coli, the original transaminase A of Rudman \& Meister (1953) is now known to consist of at least two components (Collier \& Kohlhaw, 1972; Mavrides \& Orr, 1975; Gelfand \& Steinberg, 1977; Powell \& Morrison, 1978): a tyrosine-repressible aromatic-amino-acid aminotransferase and a tyrosine-nonrepressible aspartate aminotransferase. The ability of $E$. coli to grow on Ltyrosine as sole nitrogen source (Silbert et al., 1963) thus appears to be due to the activity of the latter enzyme which is also active for the aromatic amino acids (Powell \& Morrison, 1978). However, E. coli cannot utilize L-tryptophan as sole nitrogen source in the presence of glucose, because of the great sensitivity of tryptophanase to the carbon catabolite repression (Botsford \& DeMoss, 1971). In K. aerogenes, the aminotransferase I, a constitutive enzyme, has been shown to be responsible for the utilization of the aromatic amino acids as sole sources of nitrogen (Paris \& Magasanik, $1981 a, b$ ). 


\section{REFERENCES}

AylWard, F. \& Haisman, D. R. (1969). Oxidation systems in fruits and vegetables - their relation to the quality of preserved products. Advances in Food Research 17, 1-76.

BesChle, H. G., SÜSSMUTh, R. \& LiNGENS, F. (1982). Eigenschaften von aromatischen AminosaüreAminotransferasen aus zwei Chloramphenicol-resistenten Flavobakterien. Hoppe-Seyler's Zeitschrift für physiologische Chemie 363, 1365-1375.

BOTSFORD, J. L. \& DEMoss, R. D. (1971). Catabolite repression of tryptophanase in Escherichia coli. Journal of Bacteriology 105, 303-312.

Bousfield, I. J. (1972). A taxonomic study of some coryneform bacteria. Journal of General Microbiology 71, $441-455$.

Boyaval, P., Moreira, E. \& Desmazeaud, M. J. (1984). Le transport de la phénylalanine et de la tyrosine chez Brevibacterium linens: spécificité et incorporation dans les protéines. Canadian Journal of Microbiology 30, 430-438.

BRADFORD, M. M. (1976). A rapid and sensitive method for the quantitation of microgram quantities of protein utilizing the principle of protein-dye binding. Analytical Biochemistry 72, 248-254.

Collier, R. H. \& KohlHaw, G. (1972). Nonidentity of the aspartate and the aromatic aminotransferase components of transaminase $\mathrm{A}$ in Escherichia coli. Journal of Bacteriology 112, 365-371.

Davis, B. J. (1964). Disc electrophoresis. II. Method and applications to human serum proteins. Annals of the New York Academy of Science 121, 404-427.

Dawson, R. M. C., Elliott, D. C., Elliott, W. H. \& JONES, K. M. (1969). Data for Biochemical Research, pp. 94-95. London: Oxford University Press.

Diamondstone, T. T. (1966). Assay of tyrosine transaminase activity by conversion of $p$-hydroxyphenylpyruvate to $p$-hydroxybenzaldehyde. Analytical Biochemistry 16, 395-401.

Gelfand, D. H. \& Steinberg, R. A. (1977). Escherichia coli mutants deficient in the aspartate and aromatic amino acid aminotransferases. Journal of Bacteriology 130, 429-440.

Jensen, R. A. \& CAlHoun, D. H. (1981). Intracellular roles of microbial aminotransferases: overlap enzymes across different biochemical pathways. $C R C$ Critical Reviews in Microbiology 8, 229-266.
Kradolfer, P., Niederberger, P. \& HÜtTER, R. (1982). Tryptophan degradation in Saccharomyces cerevisiae: characterization of two aromatic aminotransferases. Archices of Microbiology 133, 242-248.

Mavrides, C. \& ORR, W. (1975). Multispecific aspartate and aromatic amino acid aminotransferases in Escherichia coli. Journal of Biological Chemistry 250, 4128-4133.

Paris, C. G. \& MAgasaniK, B. (1981 a). Tryptophan metabolism in Klebsiella aerogenes: regulation of the utilization of aromatic amino acids as sources of nitrogen. Journal of Bacteriology 145, 257-265.

Paris, C. G. \& Magasanik, B. (1981 b). Purification and properties of aromatic amino acid aminotransferase from Klebsiella aerogenes. Journal of Bacteriology 145, 266-271.

Powell, J. T. \& Morrison, J. F. (1978). The purification and properties of the aspartate aminotransferase and aromatic-amino-acid aminotransferase from Escherichia coli. European Journal of Biochemistry 87, 391-400.

RudMAN, D. \& MEISTER, A. (1953). Transaminations in Escherichia coli. Journal of Biological Chemistry 205, 475-482.

Ryan, E., Bodley, F. \& Fottrell, P. F. (1972). Purification and characterization of aspartate aminotransferases from soybean root nodules and Rhizobium japonicum. Phytochemistry 11, 957-963.

Silbert, D. F., Jorgensen, S. E. \& Lin, E. C. C. (1963). Repression of transaminase $A$ by tyrosine in Escherichia coli. Biochimica et biophysica acta 73, 232240.

Sizer, I. W. \& Jenkins, W. T. (1962). Glutamic aspartic transaminase from pig ventricles. Methods in Enzymology 5, 677-684.

Whitaker, R. J., Gaines, C. G. \& Jensen, R. A. (1982). A multispecific quintet of aromatic aminotransferases that overlap different biochemical pathways in Pseudomonas aeruginosa. Journal of Biological Chemistry 257, 13550-13556.

Yagi, T., KagamiYama, H. \& Nozaki, M. (1982). Aspartate:2-oxoglutarate aminotransferase from bakers' yeast: crystallization and characterization. Journal of Biochemistry 92, 35-43. 